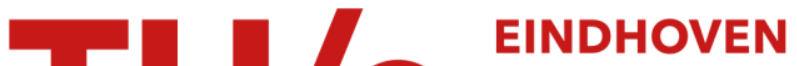 UNIVERSITY OF TECHNOLOGY
}

\section{Towards characterising design-based learning in engineering education : a review of the literature}

\section{Citation for published version (APA):}

Gomez Puente, S. M., Eijck, van, M. W., \& Jochems, W. M. G. (2011). Towards characterising design-based learning in engineering education : a review of the literature. European Journal of Engineering Education, 36(2), 137-149. https://doi.org/10.1080/03043797.2011.565116

DOI:

10.1080/03043797.2011.565116

Document status and date:

Published: 01/01/2011

\section{Document Version:}

Publisher's PDF, also known as Version of Record (includes final page, issue and volume numbers)

\section{Please check the document version of this publication:}

- A submitted manuscript is the version of the article upon submission and before peer-review. There can be important differences between the submitted version and the official published version of record. People interested in the research are advised to contact the author for the final version of the publication, or visit the $\mathrm{DOI}$ to the publisher's website.

- The final author version and the galley proof are versions of the publication after peer review.

- The final published version features the final layout of the paper including the volume, issue and page numbers.

Link to publication

\section{General rights}

Copyright and moral rights for the publications made accessible in the public portal are retained by the authors and/or other copyright owners and it is a condition of accessing publications that users recognise and abide by the legal requirements associated with these rights.

- Users may download and print one copy of any publication from the public portal for the purpose of private study or research.

- You may not further distribute the material or use it for any profit-making activity or commercial gain

- You may freely distribute the URL identifying the publication in the public portal.

If the publication is distributed under the terms of Article 25fa of the Dutch Copyright Act, indicated by the "Taverne" license above, please follow below link for the End User Agreement:

www.tue.nl/taverne

Take down policy

If you believe that this document breaches copyright please contact us at:

openaccess@tue.nl

providing details and we will investigate your claim. 


\title{
Towards characterising design-based learning in engineering education: a review of the literature
}

\author{
S.M. Gómez Puente*, M. van Eijck and W. Jochems \\ Eindhoven University of Technology, Den Dolech 2, Eindhoven 5600 MB, The Netherlands
}

(Received 18 November 2010; final version received 14 February 2011)

\begin{abstract}
Design-based learning is a teaching approach akin to problem-based learning but one to which the design of artefacts, systems and solutions in project-based settings is central. Although design-based learning has been employed in the practice of higher engineering education, it has hardly been theorised at this educational level. The aim of this study is to characterise design-based learning from existing empirical research literature on engineering education. Drawing on a perspective that accounts for domain-specific, idiosyncratic and learner-centred aspects of design problems in the context of engineering education, 50 empirical studies on project-based and problem-based engineering education, to which the design of artefacts is central, were reviewed. Based on the findings, design-based learning is characterised with regard to domain-specificity, learner expertise and task authenticity. The implications of this study for the practice of engineering education are discussed.
\end{abstract}

Keywords: design-based learning; problem-based learning; project-based learning; design tasks

\section{Introduction}

Design-based learning (DBL) is an instructional learning approach, which students in engineering design embark upon (Mehalik and Schunn 2006). Taking the design of artefacts as being central, it borrows features from problem-based learning (PBL) (Gijselaers 1996) and from problemoriented project-based learning (Kolmos 2002). In both secondary and tertiary education, DBL has been coined as a fruitful approach to learning engineering design (e.g. Wijnen 2000, Mehalik et al. 2008).

Research has yielded empirical specifications for setting up and conducting DBL at the level of secondary science and technology education (e.g. Apedoe et al. 2008). However, in higher education DBL has been hardly investigated empirically and little is known of its characteristics at this level. Hence, the aim of this study is to characterise DBL as an approach to higher engineering education.

In what follows, this paper first provides an overview of the practical and theoretical background of the state of the art of DBL in higher education. This background shapes theoretical perspective, which accounts for domain-specific, idiosyncratic and learner-focused aspects of engineering education. Next, by drawing on this perspective, 50 journal articles on project-based

*Corresponding author. Email: s.m.gomez.puente@tue.nl

ISSN 0304-3797 print/ISSN 1469-5898 online

(C) 2011 SEFI

DOI: $10.1080 / 03043797.2011 .565116$

http://www.informaworld.com 
and problem-based engineering education, to which the design of artefacts and solutions is central, were reviewed. Based on the findings, DBL is characterised in both domain-specific and generic ways, thereby pointing out critical similarities and differences with the professional practice of engineering design itself. Finally, this characterisation is explained in light of educational considerations underpinning engineering education and the implications of this study for the practice of engineering education are discussed.

\section{Background}

This section sketches the practical and theoretical background of the review study. The practical educational context underlying this study concerns the introduction of DBL as a leading principle for engineering education at Eindhoven University of Technology, now more than 10 years ago. This introduction not only yielded some preliminary characterising principles of DBL but also induced a need for further theoretical clarification of the concept and hence this literature study. This section ends by pointing out the theoretical considerations underpinning this literature study.

\subsection{Practical context}

The transition towards more learner-centred (constructivist) curricula in higher education can be taken as a particular of a worldwide recognition that the amalgam of skills and knowledge required for complex activities such as design can best be learned by doing. In technology-oriented universities in particular, this resulted in an increased interest in both PBL and project-organised learning. DBL has been coined from these two active approaches, borrowing learner-centred educational principles as well. Consequently, the aim of this concept is to motivate students as creative professionals to collectively apply knowledge and skills in newly designed systems, thereby highlighting six features, such as professionalisation, activation, cooperation, authenticity, creativity, integration and multidisciplines (Wijnen 2000).

DBL was introduced in 1997 at the Eindhoven University of Technology and it has adopted specifics from the PBL model from Maastricht University (Gijselaers 1996) and from the Aalborg University model of problem-oriented, project-based learning (Kolmos 2002). Initially, DBL had been developed as the university's central educational concept. The educational form that DBL took at the beginning in the different study programmes was based on discussions with directors of studies from the different departments (Wijnen 1999). Likewise, study tours with groups of students and teaching staff were organised to learn from the project work model of Aalborg and Roskilde universities in Denmark (Perrenet and Pleijers 2000). As a result of these experiences, DBL resembled project-like characteristics in each department. The introduction of DBL was initiated, therefore, to build experiences upon practices. This was taken as an initial step to create a platform for further innovation (Perrenet et al. 2000). In this way, the six DBL-characteristics were typified and worked out to give direction for further development and integration of DBL in the study programmes (Wijnen et al. 2000). For some programmes, the implementation of DBL led to the introduction of projects into the curriculum; whereas for others, it implied the incorporation of some educational elements in the existing projects (i.e. tutoring at the Mechanical Engineering Department). Another representation of the project work was the competence-based curriculum at the Industrial Design Department, which, as a very innovative model, has students and teachers work as junior-senior employees in realistic contexts.

DBL has been implemented for over the past 10 years but it is a concept that still needs further development. The aim of this study, therefore, is to characterise DBL as an educational concept in higher engineering education. 


\subsection{Design-based learning in higher engineering education}

Approaches centred on design problems in project-based settings are widely employed in higher engineering education. Some researchers even more strongly suggest that design exercises traditionally shape the core of design education (e.g. Dorst and Reymen 2004). Nevertheless, DBL is not always explicitly attributed to such 'DBL-like' exercises. For the purpose of this study, therefore, DBL is broadly defined to include both the concept of DBL as it has been introduced at the university as well as the many 'DBL-like approaches' described in the literature. Hence, DBL is taken as a teaching approach akin to PBL and to which the design of artefacts, systems or solutions in project-based settings is central.

In the empirical research literature, DBL has been studied mostly in the context of secondary science education (e.g. Roth 2001, Ellefson et al. 2008). Here, DBL has been employed as a vehicle for the learning of science rather than explicitly preparing for the professional practice of engineering design. This orientation does not account for epistemologies inherent to technology (van Eijck and Claxton 2009). Consequently, empirical studies on DBL in the context of secondary education often do not account for the idiosyncratic and domain-specific nature of the practice of engineering design. Hence, the outcomes of these studies cannot be transferred straightforwardly to the practice of higher engineering education.

In the context of DBL in higher education, one theoretical framework has been developed in which a more integrated, meta-perspective on design points out ways by which design can be used as an effective vehicle for learning (Mehalik and Schunn 2006). Drawing on 40 empirical studies on the nature of engineering design processes, this classification comprised both a taxonomy of engineering design elements and an indication of the frequency that these elements were reported to (potentially) constitute good design. The result is a classification of 15 design elements associated with (potentially) good design, which are reported with high, moderate or low frequency in the literature (Table 1). Particularly, the different reporting frequencies of the elements account for the idiosyncrasy.

Although the classification of Mehalik and Schunn (2006) provides some detail of possible objectives and activities inherent to DBL, it also induces problems for further research. For instance, whereas this classification focuses on the professional practice of engineering design, it is yet unknown which activities support students' preparation for such a practice and what this implies

Table 1. Database of reviewed journals

\begin{tabular}{lr} 
International Journal of Engineering Education & 11 \\
European Journal of Engineering Education & 7 \\
International Journal of Mechanical Engineering & 3 \\
$\quad$ Education & 1 \\
Journal of Engineering Technology & 1 \\
American Journal of Physics & 1 \\
Design Studies (Elsevier) & 2 \\
Chemical Engineering Education & 1 \\
Biochemistry and Molecular Biology Education & 1 \\
Computer Applications in Engineering Education & 1 \\
Progress in Robotics, Communications in Computer and & \\
$\quad$ Information Science & 16 \\
IEEE Transactions of Education & 1 \\
Journal of Information Technology Education: & 1 \\
$\quad$ Innovations in Practice & 1 \\
Computer Science Education & 1 \\
Journal of Learning Sciences & 50 \\
Journal of Professional Issues in Engineering Education & \\
Interactive Learning Environments & \\
Total & \\
\hline
\end{tabular}


for the nature of DBL-based curricula in higher engineering education. Inherently, there is a need to better understand the student expertise required for particular design activities. Furthermore, given that educational practices, as compared to professional practices, are constrained in several ways, more empirical detail is required to understand in what respect the professional practice of engineering design can function as a model for engineering design curricula. In addition to the practical aim to contribute to a better foundation of the concept of DBL in this university, this characterisation of DBL is oriented towards these gaps in the empirical literature to provide insights for educational practitioners.

\subsection{Theoretical considerations}

Given the foregoing, particular theoretical considerations are drawn on to further characterise DBL from the empirical literature. The first consideration follows from the given that the professional design enterprise is idiosyncratic in nature. On the one hand, it is recognised that characterisation of the practice of engineering design into elements such as those from Mehalik and Schunn (2006) is arbitrary. Inherently, such a classification renders design practices to particular generics that ultimately do not account for its idiosyncratic nature (Latour 1987, Dorst and van Overveld 2009). However, a classification system of design elements may be helpful to identify whether and how design elements common to professional engineering design play a role in DBL in higher engineering education. Because of its fine-grained typology of design elements, the instrument of Mehalik and Schunn (2006) is adopted. Yet, in using this instrument, it is recognised that these elements (see Table 2) in the professional practice of engineering design do not necessarily need to be sequenced one after another in time and may be present in various constellations in different forms of DBL.

Second, related to the intrinsic nature of design is its domain-specific nature. The present authors are committed to the overwhelming empirical evidence from the past 40 years that the learning

Table 2. Design elements constituting good design and their reporting frequency in engineering design studies*

Explore problem representation
Use interactive/iterative design methodology
Search the space (explore alternatives)
Use functional decomposition
Explore graphic representation
Redefine constraints
Explore scope of constraints
Validate assumptions and constraints
Examine existing designs
Explore user perspective
Build normative model
Explore engineering facts
Explore issues of measurement
Conduct failure analysis
Encourage reflection on process

Dark grey $=$ high reporting frequency; light grey $=$ moderate reporting frequency; white $=$ low reporting frequency.

*According to Mehalik and Schunn (2006). 
of techno-scientific knowledge and skills is highly domain-specific (e.g. Duit 2009). Therefore, in the characterization of DBL the differences between domains regarding the nature of design problems, as well as the relevance of particular design activities for solving these problems, are taken into account.

Third, the given that engineering design education is akin but certainly not identical to the professional practice of engineering design is drawn on. On the one hand, learning, especially in the context of preparation for complex practices such as design, can be taken as a form of participation in this practice (cf. Lave and Wenger 1990). Accordingly, DBL may include activities akin to those in professional engineering practices, eventually being fully authentic and taking place in these practices. Indeed, the six DBL characteristics is an attempt to model DBL authentically according to professional engineering practices. On the other hand, newcomers, because of their underdeveloped professional expertise, conduct particular activities in order to become experts themselves. They are not employed by experts but help to develop that expertise gradually (Atman et al. 2007). Hence, it is recognised that higher engineering curricula employing DBL-like activities are simultaneously akin to and different from professional engineering practices and exhibit different levels of authenticity.

\subsection{Research questions}

Given the theoretical considerations, the aim herein is to answer the following questions in characterising current DBL as described in the empirical literature:

(1) Which design elements of the professional practice of engineering design are common in DBL and which are not?

(2) In what respect is DBL either domain-specific or generic?

(3) In what respect does DBL account for developing the expertise of learners?

(4) Which elements of the professional practice of engineering design are common to DBL in authentic settings?

\section{Review approach}

This section explains how the journals and articles were selected for the review. The analytical approach yielding the review of the literature is then illustrated.

\subsection{Selection of journal articles}

To obtain articles for review, journals were selected that are likely to publish on educational engineering design practices indexed in the ISI Web of Science and the Education Resources Information Centre databases. A list of accepted journals of The Interuniversity Centre for Educational Research ${ }^{1}$ was also obtained. To obtain a selection of potential useful articles, the 16 selected journals were screened by using the following keywords: 'problem-based learning'; 'project-based learning'; 'design-based learning'; 'engineering design process'; 'design education'; 'design tasks'; 'engineering education'. In the selection of the articles emphasis has been made to cover a representation of engineering disciplines, such as mechanical engineering, electrical engineering, civil and environmental engineering, mining engineering, computer science, chemical, biomedical engineering and physics, among other subjects. In accordance with the definition of DBL, articles were finally selected that described problem-based, project-based learning or comparable instructional active learning methods (e.g. scenario assignments) to which the construction of artefacts or systems was central. The preliminary selection was limited to 50 articles. 


\subsection{Classification of articles}

Drawing on the theoretical considerations, several characteristics potentially relevant to DBL were determined for each article. First, to get an understanding of elements of professional design processes common to the practice of design considered significant for DBL, the reporting frequency of design elements over all articles was counted. Here, the classification of design elements of Mehalik and Schunn (2006) were followed. Since this classification consisted of precise coding of design activities reported in the articles, a second researcher independently recoded dubious cases identified by the first researcher. Yielding an initial agreement of $84 \%$, all disagreements were resolved through discussion. Furthermore, to allow comparison with the practice of professional design, the reporting frequency of design elements in the study were counted and they were compared with the design elements classified in the taxonomy of Mehalik and Schunn (2006). An element was included in the 'high reporting' category if it was focused on in more than 50\% of the articles. The element was considered to be in the 'moderate reporting' category if it was focused on in $25-50 \%$ of the articles. Finally, elements that were reported in fewer than $25 \%$ of the articles were included in the 'low reporting' category.

Second, to get an understanding of the domain-specificity of DBL, the articles were organised into three main areas according to a classification of engineering adapted from the university library. These are mechanical engineering, electrical engineering and the cluster of biomedical, chemistry and environmental engineering. Under electrical engineering, both electrical and computer engineering (hardware) and computer sciences and telecommunications engineering (software) have been clustered. One final category included the rest of the domains, such as physics, civil engineering, architecture or industrial design and graphics.

Third, to account for the level of expertise, the articles were classified according to whether they concerned courses in either graduate or undergraduate programmes or in both.

Finally, to provide detail about the authenticity of design tasks, artificial design activities were distinguished from authentic design activities. The former activities were defined as being fully carried out in educational institutions without any involvement of experts in professional engineering practice.

\section{Findings}

The results are presented in Table 2. For each design element, its frequency in the articles is given, as well as how its frequency is divided over: (a) different engineering domains; (b) educational levels; (c) authentic and artificial design activities. In the remainder of this section, these findings are briefly sketched in light of the research questions.

\subsection{DBL compared to studies on engineering design}

To gain an overview of the design elements the classification of Mehalik and Schunn (2006) were compared (Table 1), emphasising engineering design, with the results of this study (Table 2), emphasising DBL-like engineering education.

The present findings reveal differences in reporting frequencies of design elements between DBL and the professional practice of engineering design. Several design elements are reported with high frequency in engineering education (see Table 3 ) and with low or moderate frequency in professional engineering design (see Table 2): Build normative model; Explore issues of measurement; Validate assumptions and constraints; Explore graphic representation. Conversely, several design elements are reported with low or moderate frequency in the literature on DBL and with high 
Table 3. Design elements constituting good design and their reporting frequency in empirical studies on DBL in higher engineering education categorised according to domain, educational level and authenticity

\begin{tabular}{|c|c|c|c|c|c|c|c|c|c|c|}
\hline \multirow[b]{2}{*}{ Design stages } & \multicolumn{4}{|c|}{ Domain $(\%)$} & \multicolumn{3}{|c|}{ Level $(\%)$} & \multicolumn{2}{|c|}{ Authenticity (\%) } & \multirow[b]{2}{*}{$\begin{array}{l}\text { Total }(\%) \\
(\mathrm{n}=50)\end{array}$} \\
\hline & $\begin{array}{c}\mathrm{ME} \\
(\mathrm{n}=6)\end{array}$ & $\begin{array}{c}\mathrm{EE} \\
(\mathrm{n}=25)\end{array}$ & $\begin{array}{l}\text { BCEE } \\
(\mathrm{n}=7)\end{array}$ & $\begin{array}{c}\text { Other } \\
(\mathrm{n}=12)\end{array}$ & $\begin{array}{c}\mathrm{UnGr} \\
(\mathrm{n}=38)\end{array}$ & $\begin{array}{c}\mathrm{Gr} \\
(\mathrm{n}=9)\end{array}$ & $\begin{array}{c}\text { Both } \\
(\mathrm{n}=3)\end{array}$ & $\begin{array}{c}\text { Artif* } \\
(\mathrm{n}=39)\end{array}$ & $\begin{array}{l}{ }^{* *} \text { Auth }^{\dagger} \\
(\mathrm{n}=11)\end{array}$ & \\
\hline Explore problem representation & 50 & 72 & 100 & 92 & 74 & 89 & 100 & 79 & 64 & 78 \\
\hline Use interactive/iterative design methodology & 17 & 24 & 29 & 42 & 29 & 22 & 33 & 28 & 27 & 28 \\
\hline Search the space (explore alternatives) & 50 & 36 & 57 & 33 & 42 & 11 & 100 & 38 & 45 & 40 \\
\hline Use functional decomposition & 17 & 36 & 29 & 17 & 29 & 22 & 0 & 31 & 0 & 28 \\
\hline Explore graphic representation & 83 & 80 & 71 & 75 & 79 & 78 & 33 & 85 & 36 & 78 \\
\hline Redefine constraints & 33 & 16 & 29 & 8 & 18 & 0 & 67 & 15 & 18 & 18 \\
\hline Explore scope of constraints & 33 & 32 & 29 & 8 & 26 & 11 & 67 & 26 & 18 & 26 \\
\hline Validate assumptions and constraints & 67 & 80 & 100 & 92 & 89 & 78 & 67 & 92 & 55 & 86 \\
\hline Examine existing designs & 17 & 0 & 29 & 0 & 5 & 11 & 0 & 8 & 0 & 6 \\
\hline Explore user perspective & 17 & 28 & 14 & 33 & 21 & 33 & 67 & 21 & 45 & 26 \\
\hline Build normative model & 100 & 92 & 100 & 92 & 95 & 100 & 100 & 100 & 55 & 96 \\
\hline Explore engineering facts & 33 & 36 & 14 & 17 & 26 & 22 & 33 & 28 & 9 & 28 \\
\hline Explore issues of measurement & 33 & 68 & 57 & 42 & 61 & 33 & 67 & 56 & 36 & 56 \\
\hline Conduct failure analysis & 17 & 8 & 14 & 0 & 5 & 0 & 33 & 8 & 0 & 6 \\
\hline Encourage reflection on process & 17 & 8 & 29 & 25 & 16 & 0 & 33 & 10 & 27 & 16 \\
\hline
\end{tabular}

$\mathrm{DBL}=$ design-based learning; $\mathrm{ME}=$ mechanical engineering; $\mathrm{EE}=$ electrical engineering; $\mathrm{BCEE}=$ biochemical chemical and environmental engineering; $\mathrm{UnGr}=$ undergraduate $\mathrm{Gr}=\mathrm{graduate} ; \mathrm{Artif}=$ artificial activities; Auth = authentic activities.

Shading indicates a classification of reporting frequencies according to Mehalik and Schunn (2006): dark grey = high reporting frequency $(100-50 \%)$; light grey = moderate reporting frequency (50-25\%); blank = low reporting frequency $(25-0 \%)$. See also Table 2.

${ }^{*}$ Artificial refers to design project activities conducted within the educational context (i.e. university).

${ }^{\dagger}$ Authentic refers to design project activities that are conducted in closely cooperation with the industry (e.g. students conduct a research within companies, industry staff makes part of the examination committee, etc.). 
frequency in the literature on professional engineering design: Use interactive/iterative design methodology; Search the space (explore alternatives); Use functional decomposition. All these cases point to differences between the professional practice of engineering and DBL. Reported frequencies in the literature on both the professional practice of design and DBL are comparable only for the design elements 'Explore problem representation', 'Explore scope of constraints', 'Explore user perspective', 'Conduct failure analysis' and 'Encourage reflection on process'.

\subsection{Domain-specificity}

For particular design elements, some domains reveal reporting frequencies that deviate substantially from the other domains. For instance, the design element 'Explore problem representation' is reported with a lower frequency in mechanical engineering in comparison with the other domains. The difference in frequency among disciplines is also to be found in, for instance, 'Explore issues of measurement', which is remarkably lower in mechanical engineering than in the other disciplines, such as in electrical engineering. Interestingly, the design element 'Build normative model' does not differ substantially between all domains.

\subsection{Learner expertise}

Regarding the level of expertise, the differences between undergraduate and graduate level in reported frequencies of design elements are generally low. Exceptions are found in the design elements 'Search the space (explore alternatives)', 'Redefine constraints', 'Explore scope of constraints', 'Explore issues of measurement' and 'Encourage reflection on process', which are reported less frequently in articles concerning DBL in graduate programmes. In addition to this, there are some other design elements such as 'Examine existing designs', 'Explore problem representation', 'Explore user perspective', 'Build normative model', which are reported more frequently in articles focusing on the graduate level.

\subsection{Authenticity}

Finally, some substantial differences between authentic and artificial forms of DBL are observable. Particularly, the design elements 'Use functional decomposition', 'Explore graphic representation', 'Validate assumptions and constraints', 'Build normative model', 'Explore engineering facts' and 'Explore issues of measurement' are reported more frequently in articles on artificial courses than in articles on authentic courses. Conversely, counts for 'Explore user perspective' and 'Encourage reflection on process' are reported more frequently in articles on authentic courses than in articles on artificial courses.

\section{Conclusions and implications}

This section summarises the findings of the review and sketches some implications for both higher engineering design education and further research on DBL.

\subsection{Characteristics of current DBL in higher engineering education}

Regarding the reporting frequency of design elements, the characterisation of DBL reveals some critical differences with professional practice of engineering design. Most design elements are 
reported with either a substantial higher or lower frequency in the literature on DBL than in the literature of design studies. Furthermore, some design elements were found, which were reported in every article on DBL and in association with every domain, whereas others were reported in differing frequencies over different domains. Hence, DBL exhibits domain-specific elements as well as generic aspects. Strikingly, current DBL does not account substantially for developing expertise of learners with regard to either graduates or undergraduates. Regarding the reporting frequency of design elements in articles on DBL, only moderate differences were found between undergraduate and graduate courses. With regard to authenticity, some striking differences were found in reporting frequencies of design elements. That is, in articles on DBL in authentic settings, some design elements were reported substantially more frequently than in articles on DBL in artificial contexts.

Finally, in this study, several differences were found between DBL on the one hand, and good design as reported by Mehalik and Schunn (2006) on the other hand. Based on this, it is concluded that DBL is not necessarily equivalent to good design practice. Rather, DBL comprises a set of activities that prepare students for good design practices. Although DBL and good design may share many characteristics, a better understanding of DBL in educational settings implies, among other issues, considerations of how to adapt and adjust characteristics of good design practices to educational activities that support and prepare students for such a practice. This requires further research in curriculum design and in instructional approaches.

\subsection{Implications for higher engineering design education}

The substantial differences in reporting frequencies of design elements between the literature on professional design and current DBL induces the question of in what respect the latter can be considered either preparatory for the practice of design or a vehicle for learning specific design elements, such as 'Building a normative model' or 'Exploring graphic representations'. On the other hand, since such design elements are relatively easily assessable as products, the high reporting frequency in DBL may also be caused by specific constraints of education in undergraduate courses in particular, such as efficiency, testability and accountability. Nonetheless, these findings imply that engineering educators should consider the precise pedagogical function of DBL in their educational programmes. The pertinence of this implication also follows from the substantial differences in reporting frequencies of design elements between either professional design practices or DBL, as well as between either authentic or less authentic contexts. Especially, the latter finding induces the question of in what respect is DBL in artificial settings preparatory for the professional practice of designers. This is not necessarily the case. For instance, DBL in artificial settings in undergraduate courses may be predominantly used as a vehicle to learn particular engineering skills more generally. If this is the case, such courses may be appropriate vehicles to learn skills associated with more generic design elements in DBL, such as 'Building a normative model', 'Exploring problem representation', 'Exploring graphic representations' and 'Validate assumptions and constraints'. On the other hand, if expert participation in the professional practice of design is the ultimate aim of DBL, the developing expertise in the route from novice to expert through undergraduate and graduate courses should imply careful consideration. Particularly relevant are the nature of both the design activities to be practised and the authenticity of the context wherein these activities are conducted. Such considerations may support educators to develop curricula that reflect more substantial differences between undergraduate and graduate forms of DBL. Related to this implication is the consideration of the domain-specificity of design courses. Given that DBL is domain-specific, every course should be developed accordingly. Nevertheless, educators should also be aware of more generic elements of DBL in the design of curricula, from novice to professional expertise. 


\subsection{Implications for further research on $D B L$ in higher engineering design education}

The outcomes point out a need for further research in several directions. One avenue for further explorations concerns the question of in what respect DBL can be considered either as preparatory for the practice of design or as a vehicle for learning specific design elements. This requires empirical research in association with educators who employ forms of DBL that are comparable to the ones reported in the literature. Of critical importance is the question of how the learning outcomes of these forms of DBL are considered and how these relate to levels of authenticity and learner expertise. Also relevant is the question of to what respect goals reported as relevant to DBL educators are either generic aims or specific to their domain. Another avenue for further research concerns the substantial differences in reporting frequencies of design elements in the literature on DBL either in itself or as related to the professional literature. This opens up the question of which design elements are considered relevant to educators for what particular reasons, as related to the domain they are working in, the outcomes of their courses and, related to the former implication, the authenticity and domain-specificity of the setting of their courses. Again, this requires empirical research in collaboration with professional educators developing and conducting DBL-like courses in higher engineering education. It also requires further research to gain insights from the literature in curriculum and instructional approaches related to the practice of engineering design education.

\section{Note}

1. The Interuniversity Centre for Educational Research is the Dutch PhD research school for educational sciences formally recognised by the Royal Netherlands Academy of Arts and Sciences. The academic board of the organisation maintains a list of non-ISI journals of acceptable academic quality in which its members can publish (http://www.ou.nl/eCache/DEF/1/93/759.html).

\section{References}

Apedoe, X.S., et al., 2008. Bringing engineering design into high school science classrooms: the heating/cooling unit. Journal of Science Education Technology, 17 (5), 454-465.

Atman, C.J., et al., 2007. Engineering design processes: a comparison of students and expert practitioners. Journal of Engineering Education, 96 (4), 359-379.

Dorst, K. and Reymen, I.M.M.J., 2004. Levels of expertise in design education. In: P. Lloyd, N. Roozenburg, C. McMahon and L. Brodhurst, eds. Proceedings of the 2 nd international engineering and product design education conference, Delft: Delft University of Technology, 159-166.

Dorst, K. and van Overveld, K., 2009. Typologies of design practice. In: D.M. Gabbay, A. Meijers, P. Thagard and J. Woods, eds. Philosophy of technology and engineering sciences. Burlington, MA: North Holland, 455-488.

Duit, R., 2009. Bibliography STCSE: Students' and teachers' conceptions and science education [online]. Kiel, Germany: IPN - Leibniz Institute for Science Education. Available from: http://www.ipn.uni-kiel.de/aktuell/stcse/stcse.html [Accessed 2 October 2010].

Ellefson, M.R., et al., 2008. Design-based learning for biology: genetic engineering experience improves understanding of gene expression. Biochemistry and Molecular Biology Education, 36 (4), 292-298.

Gijselaers, W.H., 1996. Connecting problem-based practices with educational theory. In: L. Wilkerson and W. Gijselaers, eds. Bringing problem-based learning to higher education: Theory and practice. New directions in teaching and learning, No. 68, Winter 1996. San Francisco: Jossey Bass, 13-21.

Kolmos, A., 2002. Facilitating change to a problem-based model. The International Journal for Academic Development, 7 (1), 63-74.

Latour, B., 1987. Science in action: How to follow scientists and engineers through society. Cambridge, MA: Harvard University Press.

Lave, J. and Wenger, E., 1990. Situated learning: Legitimate peripheral participation. Cambridge: Cambridge University Press.

Mehalik, M.M., Doppelt, Y. and Schunn, C.D., 2008. Middle-school science through design-based learning versus scripted inquiry: better overall science concept learning and equity gap reduction. Journal of Engineering Education, 97 (1), 1-15.

Mehalik, M.M. and Schunn, C., 2006. What constitutes good design? A review of empirical studies of design processes. International Journal of Engineering Education, 22 (3), 519-532. 
Perrenet, J.C., Bouhuijs, P.A.J. and Smits, J.G.M.M., 2000. The suitability of problem-based learning for engineering education: theory and practice. Teaching in Higher Education, 5 (3), 345-358.

Perrenet, J.C. and Pleijers, A.J.S.F., 2000. OGO over de grens: verslag van een interfacultaire studiereis naar Denemarken, OGO-brochure no.3. Eindhoven: Eindhoven University of Technology, Educational Service Centre.

Roth, W.-M., 2001. Learning science through technological design. Journal of Research in Science Teaching, 38 (7), $768-790$

van Eijck, M. and Claxton, N.X., 2009. Rethinking the notion of technology in education: techno-epistemology as a feature inherent to human praxis. Science Education, 93 (2), 218-232.

Wijnen, W.H.F.W., 1999. Op weg naar ontwerpgericht onderwijs. Eindhoven: Eindhoven University of Technology, Educational Service Centre.

Wijnen, W.H.F.W., 2000. Towards design-based learning. Eindhoven: Eindhoven University of Technology, Educational Service Centre.

Wijnen, W.H.F.W., et al., 2000. Naar een nieuw evenwicht: uitwerking van de zes hoofdkenmerken van Ontwerpgericht Onderwijs, OGO-brouchure no. 2. Eindhoven: Eindhoven University of Technology, Educational Service Centre.

\section{Appendix 1: Reviewed journal articles}

Baldock, T.E. and Chanson, H., 2006. Undergraduate teaching of ideal and real flows: the value of real world experimental projects. European Journal of Engineering Education, 31 (6), 729-739.

Baley, R., 2006. Assessing engineering design process knowledge. International Journal Engineering Education, 22 (3), $508-518$

Behrens, A., et al., 2010. MATLAB Meets LEGO Mindstorms - a freshman introduction course into practical engineering. IEEE Transactions on Education, 53 (2), 306-317.

Chang, G.-W., et al., 2008. A progressive design approach to enhance project-based learning in applied electronics through an optoelectronic sensing project. IEEE Transactions on Education, 51 (2), 220-233.

Cheville, R.A., McGovern, A. and Bull, K.S., 2005. The light applications in science and engineering research collaborative undergraduate laboratory for teaching (LASE CULT)-relevant experiential learning in photonics. IEEE Transactions on Education, 48 (2), 254-263.

Chinowsky, P.S., et al., 2006. Developing knowledge landscapes through project-based learning. Journal of Professional Issues in Engineering Education and Practice, 132 (2), 118-124.

Clyde, S.W. and Crane, A.E., 2003. Design-n-code fests. Computer Science Education, 13 (4), 289-303.

Costa, L.R.J., Honkala, M. and Lehtovuori, A., 2007. Applying the problem-based learning approach to teach elementary circuit analysis. IEEE Transactions on Education, 50 (1), 41-48.

Denayer, I., et al., 2003. Teaching a structured approach to the design process for undergraduate engineering student by problem-based education. European Journal of Engineering Education, 28 (2), 203-214.

Etkina, E., Murthy, S. and Zou, X., 2006. Using introductory labs to engage students in experimental design. American Journal of Physics, 74 (11), 979-986.

Etkina, E., et al., 2010. Design and reflection help students develop scientific abilities: learning in introductory physics laboratories. The Journal of the Learning Sciences, 19, 54-98.

Friesel, A., 2009. Teamwork and robot competitions in the undergraduate program at the Copenhagen University College of Engineering. Progress in Robotics, Communications in Computer and Information Science, 44, 279-286.

Geber, E., 2010. Learning to waste and wasting to learn? How to use cradle to cradle principles to improve the teaching of design. International Journal of Engineering Education, 26 (2), 314-323.

Hassan, H., et al., 2008. Integrated multicourse project-based learning in electronic engineering. International Journal of Engineering Education, 24 (3), 581-591.

Hirsch, P.L., et al., 2001. Engineering design and communication: the case for interdisciplinary collaboration. International Journal of Engineering Education, 17 (4), 342-348.

Hung, I.W. and Choi, A.C.K., 2003. An integrated problem-based learning model for engineering education. International Journal of Engineering Education, 19 (5), 734-737.

Jacobson, M.L., Said, R.A. and Rehman, H., 2006. Introducing design skills at the freshman level: structured design experience. IEEE Transactions on Education, 49 (2), 247-253.

Kalkani, E.C., Boussiakou, I.K. and Boussiakou, L.G., 2005. The paper beam: hands-on design for team work experience of freshman in engineering. European Journal of Engineering Education, 30 (3), 393-402.

Kecojevic, V., Bise, C. and Haight, J., 2005. The effective use of professional software in an undergraduate mining engineering curriculum. Interactive Learning Environments, 13 (1-2), 1-13.

Kimmel, S.J. and Deek, F.P., 2004. Using a problem-solving heuristic to teach engineering graphics. International Journal of Mechanical Engineering, 32 (2), 135-146.

Kimmel, S.J., Kimmel, H.S. and Deek F.P., 2003. The common skills of problem solving: from program development to engineering design. International Journal of Engineering Education, 19 (6), 810-817.

Kundu, S. and Fowler, M.W., 2009. Use of engineering design competitions for undergraduate and capstone projects. Chemical Engineering Education, 43 (2), 131-136.

Lee, Ch.-Sh., et al., 2010. A project-based laboratory for learning embedded system design with industry support. IEEE Transactions on Education, 53 (2), 173-181. 
Lemons, G., et al., 2010. The benefits of model building in teaching engineering design. Design Studies, 31 (3), 288-309.

Linge, N. and Parsons, D., 2006. Problem-based learning as an effective tool for teaching computer network design. IEEE Transactions on Education, 49 (1), 5-10.

Lyons, J.S. and Brader, J.S., 2004. Using the learning cycle to develop freshmen's abilities to design and conduct experiments. International Journal of Mechanical Engineering Education, 32 (2), 126-134.

Maase, E.L., 2008. Activity problem solving and applied research methods in a graduate course on numerical methods. Chemical Engineering Education, 42 (1), 23-32.

Macías-Guarasa, J., et al., 2006. A project-based learning approach to design electronic systems curricula. IEEE Transactions on Education, 49 (3), 389-397.

McKenna, A., et al., 2006. IDEA: formalizing the foundation for an engineering design education. International Journal of Engineering Education, 22 (3), 671-678.

McMartin, F., McKenna, A. and Youssefi, K., 2000. Scenario assignments as assessment tools for undergraduate engineering education. IEEE Transactions on Education, 43 (2), 111-119.

Martínez Monés, A., et al., 2005. Multiple case studies to enhance project-based learning in a computer architecture course. IEEE Transactions on Education, 48 (3), 482-488.

Massey, A.P., Ramesh, V. and Khatri, V., 2006. Design, development and assessment of mobile applications: the case for problem-based learning. IEEE Transactions on Education, 49 (2), 183-192.

Mese, E., 2006. Project-oriented adjustable speed motor drive course for undergraduate curricula. IEEE Transactions on Education, 49 (2), 236-246.

Mistikoglu, S. and Özyalçin, I., 2010. Design and development of a Cartesian robot for multi-disciplinary engineering education. International Journal of Engineering Education, 26 (1), 30-39.

Nedic, Z., Nafalski, A. and Machotka, J., 2010. Motivational project-based laboratory for a common first year electrical engineering course. European Journal of Engineering Education, 35 (4), 379-392.

Nonclercq, A., et al., 2010. Problem-based learning in instrumentation: synergism of real and virtual modular acquisition chains. IEEE Transactions on Education, 53 (2), 234-242.

Nooshabadi, S. and Garside, J., 2006. Modernization of teaching in embedded systems design - an international collaborative project. IEEE Transactions on Education, 49 (2), 254-262.

Otieno, A., Azad, A. and Balamuralikrishna, R., 2006. Creating a bridge to stimulate simultaneous engineering experiences for senior undergraduate students. European Journal of Engineering Education, 31 (2), 181-189.

Padgett, W.T., Black, B.B. and Ferguson, B.A., 2006. Low-frequency wireless communications system - infrared laboratory experiments. IEEE Transactions on Education, 49 (1), 49-57.

Ringwood, J.V., Monaghan, K. and Malaco, J., 2005. Teaching engineering design through Lego mindstorms. European Journal of Engineering Education, 30 (1), 91-104.

Roberts, L., 2001. Developing experimental design and troubleshooting skills in an advanced biochemistry lab. Biochemistry and Molecular Biology Education, 29, 10-15.

Schäfer, A.I. and Richards, B.S., 2007. From concept to commercialization: student learning in a sustainable engineering innovation project. European Journal of Engineering Education, 32 (2), 143-165.

Selfridge, R.H., Schultz, S.M. and Hawkins, A.R., 2007. Free-space optical link as a model undergraduate design project. IEEE Transactions on Education, 50 (3), 208-215.

Shyr, W.-J., 2009. Teaching mechatronics: an innovative group project-based approach. Computer Applications in Engineering Education, [preprint]. Available from: http://onlinelibrary.wiley.com/doi/10.1002/cae.20377/abstracts.

Spezia, C.J., 2009. A task-oriented design project for improving student performance. Journal of Engineering Technology, 26 (1), 24-30.

Stankovic, N., Tillo, T. and Jiaotong, X., 2009. Concurrent software engineering project. Journal of Information Technology Education: Innovations in Practice, 8, 27-41.

Stiver, W., 2010. Sustainable design in a second year engineering design course. International Journal of Engineering Education, 26 (2), 378-383.

van Til, R.P., et al., 2009. Teaching lean with an interdisciplinary problem-solving learning approach. International Journal Engineering Education, 25 (1), 173-180.

Wood, J., et al., 2005. Enhancing the teaching of machine design by creating a basic hands-on environment with mechanical 'breadboards'. International Journal of Mechanical Engineering Education, 33 (1), 1-25.

Zhan, W. and Porter, J.R., 2010. Using project-based learning to teach six sigma principles. International Journal of Engineering Education, 26 (3), 655-666.

\section{About the authors}

Sonia M. Gómez Puente is a $\mathrm{PhD}$ candidate at the Eindhoven School of Education and Teacher Trainer at TEACH, the Department of Education and Training at the Eindhoven University of Technology (TU/e). Her interest lies in curriculum development, instructional design, and in activating teaching methods. She trains teachers in design-based learning and in supervising group projects. 
Michiel van Eijck is Assistant Professor of Science Education at the Eindhoven School of Education at the Eindhoven University of Technology. His research focuses on the professional development of science and technology teachers. He is particularly interested in the role of authentic, diverse and dynamic learning environments.

Wim Jochems is Dean and Full Professor of Educational Innovation at the Eindhoven School of Education at the Eindhoven University of Technology, the Netherlands. His research focuses on innovation of science and technology education. He is particularly interested in the role of science teachers in implementing educational innovations. 